\title{
Biochemical Composition of Propolis and Its Efficacy in Maintaining Postharvest Storability of Fresh Fruits and Vegetables
}

\author{
İbrahim Kahramanoğlu (iD, ${ }^{1}$ Volkan Okatan, ${ }^{2}$ and Chunpeng Wan ${ }^{3}{ }^{3}$ \\ ${ }^{1}$ European University of Lefke, Gemikonagi, Northern Cyprus, Mersin 10, Turkey \\ ${ }^{2} U_{s ̧ a k}$ University, Faculty of Agriculture and Natural Sciences, Department of Horticulture. Uşak, Uşak, Turkey \\ ${ }^{3}$ Jiangxi Key Laboratory for Postharvest Technology and Nondestructive Testing of Fruits \& Vegetables/Collaborative \\ Innovation Center of Postharvest Key Technology and Quality Safety of Fruits \& Vegetables in Jiangxi Province, \\ College of Agronomy, Jiangxi Agricultural University, Nanchang 330045, China
}

Correspondence should be addressed to Chunpeng Wan; chunpengwan@jxau.edu.cn

Received 24 April 2020; Revised 9 June 2020; Accepted 14 July 2020; Published 29 July 2020

Academic Editor: Elena Gonz lez Fandos

Copyright (C) 2020 İbrahim Kahramanoğlu et al. This is an open access article distributed under the Creative Commons Attribution License, which permits unrestricted use, distribution, and reproduction in any medium, provided the original work is properly cited.

\begin{abstract}
Propolis, also called "bee-glue," is a natural resinous substance produced by honeybees from plant exudates, beeswax, and bee secretions in order to defend the hives. It has numerous phenolic compounds with more than 250 identified chemical compounds in its composition, which are also known to significantly vary according to the plant sources and season. Moreover, it has a long history in the traditional and scientific medicine as having antibacterial, anticancer, anti-inflammatory, anti-infective, and wound healing effects since $300 \mathrm{BC}$. In addition to its nutritional and health-promoting effects, it has been reported to improve the postharvest storability of fresh fruits, vegetables, and processed food products. Herein, the biochemical composition and the efficacy of propolis in maintaining the postharvest storability of fresh food products were discussed to provide comprehensive guide to farmers and food processing and storage sectors and to scientists. This review paper also highlights the important points to which special attention should be given in further studies in order to be able to use propolis to develop biopreservatives industrially and for quality preservation during storage.
\end{abstract}

\section{Introduction}

Numerous scientists warn humanity about the fact that the most important global issues in near future will be food safety and security. It has been estimated that by 2050 , the human population worldwide will exceed 9 billion while the available natural resources required for food production (i.e., soil and water) have a diminishing trend [1-4]. This will unfortunately make it impossible, or let us be a little more positive, very difficult to feed the humanity and to ensure the health of the planet and humanity, if suitable measures are not taken. It is not that difficult to come up with this thought, when the reports of the FAO [5] says that around 821.6 million people ( $10.8 \%$ of the total population) have suffered from chronic hunger in 2018. To overcome this challenge in large scale, one widely appraised solution is to address these four pillars: food availability, access, utilization, and stability $[6,7]$. As seen from the appraised solution, food utilization (handling and storage) is as important as its production. It was estimated that the postharvest loss during utilization throughout the world is around $30-50 \%$, depending on the product and place; and it goes to waste $[3,8]$. This alone is an important part of the four pillars of the solution. Thus, efficient and safe measures are of utmost importance to reduce postharvest loss and wastes during harvesting, processing, storage, distribution, and retail and in households.

Agrochemicals have a vital role in production, protection, and preservation of the fresh products and are still the primary preferences of growers for crop production and 
prevention of food losses [9]. However, it has been reported that the misuse of chemical fungicides reduces the efficacy of the fungicides by causing resistant fungi strains [10]. Besides the reducing efficacy of agrochemicals in time, excessive use of agrochemicals has been the subject of public discussions among scientists, consumers, and the media, and this reduces their acceptability by the consumers $[11,12]$. Thus, this is a double-edged challenge for the growers as they have to reduce/eliminate postharvest losses to ensure food security, while at the same time they have to ensure food safety by eliminating any negative effects of agrochemicals. At this point, development of alternative human/ecofriendly measures to agrochemicals has been an important subject for the scientific world [13]. In this context, numerous studies have been conducted to develop human/ecofriendly alternatives and suggested many biomaterials or measures for the prevention of the postharvest losses: hot water dipping (HWD) [14], hot air treatment (HAT) [15], salts [16], light irradiation [17], modified atmosphere packaging (MAP) [18], edible coatings [19,20], plant extracts [21-24], essential oils $[25,26]$, chitosan $[27,28]$, and propolis $[29,30]$. Among these, propolis has an important role in prevention of food loss and waste, thus helping to ensure food safety and security. Herein, the biochemical composition and efficacy of propolis in maintaining the postharvest storability of food products were discussed to provide a comprehensive guide to farmers and food processing and storage sectors and to scientists.

\section{Biochemical Composition (Phenolic Acids, Flavonoids, Vitamins, and Others)}

Propolis is a natural hive defensive resinous substance produced by honeybees from plant exudates, beeswax, and bee secretions. Propolis which is also called "bee-glue" is collected by honeybees from a variety of plant resinous secretions, i.e., gums, resins, leaf buds, and mucilage [31, 32], from numerous plant species, such as conifers, pine, palm, poplar, and birch [33], and is used to build structures in their hives and to fill the holes in to protect their hives from microbes and other external threats [34]. It has a long history in medicine as a wound healing agent and having antibacterial, anticancer, anti-inflammatory, and anti-infective effects since 300 BC [35-39]. It is reported that its composition significantly varies according to the plant sources and season and it is composed of about $50 \%$ resin, 30\% wax, $10 \%$ essential oils, $5 \%$ pollen, and $5 \%$ other substances [34]. According to the review of Anjum et al. [40], the numbers of identified chemical components of propolis have exceeded 250. The general groups of the chemical components are alcohol and its derivatives, aliphatic acids, aliphatic esters, aliphatic hydrocarbons, amino acids, benzaldehyde derivatives, benzoic acid and its derivatives, cinnamic acid and its derivatives, dihydrochalcones, enzymes, esters, fatty acids (C7-C18 acids), flavonoids, heteroaromatic compounds, ketones, minerals, nicotinic acid, pantothenic acid, chalcones, phenols, sesquiterpene, sesquiterpene, steroid hydrocarbons, sterols, sugar, terpene, triterpene hydrocarbons, vitamins, and waxy acids. The chemical composition of propolis was noted to have high variation apparently related to plant sources [41].

In one of the most recent studies, Chaa et al. [42] tested the chemical composition of ethyl acetate extract of propolis (EAP: $10 \mathrm{~g}$ of crude propolis crushed and extracted three times with ethanol 95\%) collected from Tigzirt, Algeria. Researchers noted that the chemical composition of the propolis samples which were made by a certain breed of bees (Apis mellifera intermissa) have 17 different chemical compounds. They noted that the main phenolic compound was caffeic acid $\left(0.85 \mathrm{mg}^{-1} \mathrm{EAP}\right)$ and the main flavonol compound was pinocembrin $\left(0.82 \mathrm{mg} \cdot \mathrm{g}^{-1} \mathrm{EAP}\right)$. A study on propolis extracts collected from Polland showed that the chemical composition highly depends on the season [43]. In this study, samples were reported to be collected in three different seasons: spring ( $4^{\text {th }}$ to $6^{\text {th }}$ month), summer ( $6^{\text {th }}$ to $9^{\text {th }}$ month), and fall ( $9^{\text {th }}$ to $11^{\text {th }}$ month). The extraction method of the propolis in that study differed from the studies in [42], where $70 \%$ ethanol was used in $1: 10(w / v)$ and the solution was called ethanolic extracts of propolis (EEP). The highest sums of the determined flavonoids and phenolic acids were both noted in the samples harvested in spring as 125.14 and $19.34 \mathrm{mg} \cdot \mathrm{g}^{-1}$, respectively. The lowest sum of the phenolic acids was noted in the summer samples $\left(16.18 \mathrm{mg} \cdot \mathrm{g}^{-1}\right)$, where the lowest sum of total flavonoids was in the samples of fall season $\left(110.09 \mathrm{mg} \cdot \mathrm{g}^{-1}\right)$ (Table 1).

The main flavonol compound was found to be pinocembrin, but the concentrations were very high in EEP extracts as compared with EAP. Most of the flavonoids in these studies were common, but some were not, such as acacetin, myricetin, and galangin. Similar results were noted by Valencia et al. [45] for Sonoran propolis. In the mentioned study, it was noted that the both phenolic acids and flavonoids decrease in spring, while the total phenolics are highest in fall and total flavonoids are highest in summer [45]. These biochemical compounds are known to have high antioxidant and antimicrobial activities [44]. The propolis samples have also been suggested to be divided into two main groups, orange $(\mathrm{O})$ and blue $(\mathrm{B})$, according to the colours of the phenolic profiles in HPTLC analysis [46, 47], but a third group was also noted by some reports as green $(G)$ or third band $[44,48]$. The bands with strong orange colour are distinctive with flavonoids (i.e., quercetin) and the blue bands generally include caffeic acid. A summary was given in Table 1 for the Turkish propolis subtypes [44].

\section{Antimicrobial and Fungicidal Effects}

Microbial decay caused by fungi and/or bacteria is an important problem for the postharvest storability of the food products, including fresh fruits and vegetables and processed foods. It has been reported to reach very high levels in different kinds of fruits such as Penicillium italicum Wehmer (blue mold) and was noted to cause up to $80 \%$ loss in citrus fruits [49]. Due to the scientifically confirmed health benefits of the propolis, most of the previous studies about the fungicidal effects of propolis have been conducted on the human damaging microbes, such as Candida albicans [44]. The strong antimicrobial activity of the propolis extracts was 
Table 1: Phenolic compositions of different propolis derivates from different plant sources, seasons, and types.

\begin{tabular}{|c|c|c|c|c|c|c|c|}
\hline \multirow{2}{*}{ Phenolics } & \multirow{2}{*}{$\mathrm{mg} \cdot \mathrm{g}^{-1}$ of EAP [42] } & \multicolumn{3}{|c|}{$\mathrm{mg} \cdot \mathrm{g}^{-1}$ of EEP [43] } & \multicolumn{3}{|c|}{$\mathrm{mg} \cdot \mathrm{mL}^{-1}$ of EEP [44] } \\
\hline & & Spring & Summer & Fall & Orange-type & Blue-type & Green-type \\
\hline \multicolumn{8}{|l|}{ Phenolic acids } \\
\hline Caffeic acid & 0.85 & 3.90 & 3.26 & 3.68 & 34.78 & 24.82 & 3.96 \\
\hline Ellagic acid & 0.60 & No & No & No & No & No & No \\
\hline p-Coumaric acid & 0.41 & 10.00 & 9.17 & 10.04 & 4.91 & 3.13 & 0.19 \\
\hline Cinnamic acid & 0.34 & No & No & No & 5.19 & 3.00 & 5.28 \\
\hline Gallic acid & 0.29 & No & No & No & No & No & No \\
\hline Chlorogenic acid & 0.20 & No & No & No & No & No & No \\
\hline Rosmarinic acid & 0.18 & No & No & No & No & No & No \\
\hline Ferulic acid & 0.05 & 3.80 & 2.61 & 3.63 & 19.42 & 9.63 & 1.00 \\
\hline Vanillic acid & No & 0.46 & 0.31 & nd & 0.39 & 0.30 & 0.27 \\
\hline Syringic acid & No & 1.18 & 0.83 & 1.01 & No & No & No \\
\hline Protocatechuic acid & No & No & No & No & 1.69 & 0.71 & 0.45 \\
\hline \multicolumn{8}{|l|}{ Flavonoids } \\
\hline Pinocembrin* & 0.82 & 51.55 & 41.55 & 50.34 & 2.81 & 2.16 & 0.94 \\
\hline Catechin & 0.78 & No & No & No & No & No & No \\
\hline Quercetin & 0.76 & 4.29 & 4.03 & 3.83 & 4.33 & 2.85 & 1.11 \\
\hline Chrysin & 0.55 & 19.51 & 14.40 & 15.32 & 2.22 & 1.85 & 1.54 \\
\hline Kaempferol & 0.31 & 10.43 & 11.51 & 5.01 & 1.76 & 0.92 & 0.44 \\
\hline Acacetin & 0.17 & No & No & No & No & No & No \\
\hline Rutin & 0.01 & 0.72 & 0.56 & 0.49 & 0.36 & 0.47 & 0.16 \\
\hline Apigenin & 0.01 & 6.03 & 7.94 & 10.01 & No & No & No \\
\hline Myricetin & No & 0.63 & 0.39 & 0.83 & No & No & No \\
\hline Galangin & No & 26.89 & 32.53 & 20.14 & 2.70 & 1.67 & 0.96 \\
\hline Naringenin & No & 0.88 & 0.83 & 0.83 & No & No & No \\
\hline Pinobanksin & No & 4.21 & 3.83 & 3.29 & No & No & No \\
\hline Luteolin & No & No & No & No & 1.57 & 0.24 & 0.31 \\
\hline Apigenin & No & No & No & No & 1.56 & 1.05 & 0.54 \\
\hline
\end{tabular}

No represents "no available information"; nd means "not detected" from Turkey. *Flavanone: a type of flavonoid.

attributed to the high concentrations of cinnamic acid, ferulic acid, and caffeic acid [50,51]. Furthermore, there are numerous studies about its efficacy on food damaging pathogens. In general, two different mechanisms were suggested in the literature for the antimicrobial efficacy of the propolis: (1) direct influence on the pathogens by prevention of some biochemical reactions and (2) improving resistance of products to the pathogens by enhancing some other biochemical reactions [52-55].

Ethanolic extracts of propolis (first dissolved in 70\% ethanol in a ratio of $1: 10(w / v)$ and then diluted with pure water in a ratio of $1: 10(w / v)$ to obtain $1.0 \%$ dose) was reported to significantly reduce gray mold (Botrytis cinera) development on pomegranate fruits [30]. The studies on pomegranate fruits also suggested that the EEP has a significant influence on the prevention of the antioxidant activity and anthocyanin contents, which might be attributed to the fungicidal activity of the propolis. By following the same extraction method, $0.5 \%$ dose of EEP then showed to have a potential to reduce the microbial growth on the cucumber fruits [56]. Different doses (30, 50, 70, and 100\%) of ethanolic extract of propolis (EEP) (ratio of propolis to $80 \%$ ethanol was $1: 10 \mathrm{w} / \mathrm{v}$ ) was noted to significantly reduce the growth of 19 different yeast strains isolated from industrial foods in in vitro conditions. It was noted that the antimicrobial ability of EEP against the yeast strains differ significantly where the lowest effect was suggested for
Candida famata and the highest efficacy for Candida laurentii. The efficacy of the propolis was attributed to its characteristics in inhibition of cell division and causing cell rupture [57]. Similar results were previously suggested by Takaisi-Kikuni and Schilcher [58] who reported that the propolis have a possible mechanism for inhibiting cell division and causing surface alteration of the cells. The inhibitory effects of propolis, in a different study, was also attributed to the possible mechanism for inhibiting protein synthesis and some functions of the cell membrane, where the flavonoid quercetin was suggested to be responsible for this mechanism [50]. The study by Alsayed et al. [57] also showed that the propolis treatment reduces the activity of oxidative enzymes, together with catalase activity, superoxide dismutase activity, and ascorbate activity in yeast. Oxidative enzymes are important for the catalyzation of the oxidation reaction and reduction in these activities and might be a cause of the discouraging the growth of the yeast. Similarly, the application of propolis was noted to reduce reactive oxygen species (ROS) generation and lipid peroxidation [57]. In an in vitro experiment with mango fruits (var "Kent"), different doses of propolis $(0,0.25,0.5,1.0,1.5$, and $2.0 \% \mathrm{w} / \mathrm{v}$ ) were tested against anthracnose development and reported that the $1.5 \%$ dose is highly effective in spore suspension [53]. Application of propolis was also found to significantly induce inhibition of the mycelial growth of Penicillium digitatum $[59,60]$. In each of these studies, the 
capability of propolis to inhibit the pathogenic development was attributed to its high contents of phenolic compounds. The application of propolis to the plants or fruits was also noted to enhance $\mathrm{Cu} / \mathrm{Zn}-\mathrm{SOD}$ and protect plant cells, thus improving the resistance of the crops to the pathogens. The antimicrobial efficacy of propolis was confirmed in a number of studies for mango fruits [53, 55], papaya fruits [52], orange $[54,61]$, and pomegranate juice [62]. Antifungal activity of ethanolic extract of propolis was also tested on raspberry fruits against $P$. digitatum, $P$. expansum, $P$. italicum, A. alternata, A. carbonarius, and B. cinerea. Gelatinbased edible coatings by propolis were tested, and the active films showed a high antifungal activity against the tested fungus [63]. It was also noted that the incorporation of propolis with chitosan provides higher antimicrobial activity $[64,65]$. In one of these studies, Correa-Pacheco et al. [64] noted that the propolis-containing formulations (10\%, $20 \%$, and $30 \%$ ) had a strong inhibitory effect on Listeria monocytogenes and $10 \%$ formulation had a similar effect on Escherichia coli and provided better preservation of strawberries. In a different study, in vivo and in vitro trials were conducted to test the efficacy of propolis extracts on the Stemphylium vesicarium (Wallr.) E. G., which is the cause of brown spot disease in pear fruits. Researchers noted that the propolis extracts provides $90 \%$ reduction in the mycelial growth in in vitro studies and up to $57 \%$ in in vitro studies [66].

Previous studies also recommended that ethanol, methanol, alcohol, acetone, or some other solvents may have a significant influence on some fungus and/or bacteria [67-69]. However, nearly all of the studies on propolis also tested the efficacy of the solvent and those studies reported that although the solvent might improve the efficacy of propolis, the antimicrobial and fungicidal efficacies are mainly due to the propolis itself.

\section{Effects on Food Quality Characteristics}

Food quality characteristics are generally classified in three groups, which are (1) external quality characteristics (visual quality, size, colour, etc.) (2) internal quality characteristics (internal colour, juice content, texture, taste, number of seeds, etc.), and (3) hidden quality characteristics (nutritional status and safety) [3]. The aim of the postharvest handling is not only to maintain the external quality characteristics, but also the internal quality attributes, without damaging the hidden quality characteristics of the foods. In this context, propolis as a natural product has a significant role in maintaining the postharvest storability of food products. Results of existing literature was discussed in the following sections, separately for each quality parameter, and a summary is presented in Table 2 .

4.1. Effects on Weight Loss. Weight loss, together with the microbial decay, could be accepted as the most important problems related with postharvest storage of the foods. The main reasons of the weight loss are the ongoing transpiration (loss of water from the living tissues) and the respiration (loss of carbohydrates) of the foods after harvest/processing $[3,78]$. Thus, reducing the weight loss is highly related with the reduction of respiration and transpiration. The hydrophobic composites of propolis extracts, with its high phenolic concentration, are capable of forming a biodegradable barrier on fruit surface which prevents the movement of water and gaseous through the food surface [73, 74]. In confirmation of this knowledge, propolis treatment has been reported to reduce weight loss of various foods during storage such as pomegranate [30], mango [55], papaya [52, 70, 71], banana [72], dragon fruit [73], orange $[54,61,74]$, and cucumber [56]. Such reduction in the weight loss might be explained by the characteristics of propolis about the prevention of transpiration and respiration. In one of these studies, the ethanolic extracts of propolis, at a rate of $1.0 \%$, were found to protect pomegranate fruit weight during storage at $6.5 \pm 1{ }^{\circ} \mathrm{C}$ and $90-95 \%$ relative humidity. It was noted that the weight losses of fruits treated with propolis and those untreated were $11.3 \%$ and $19.8 \%$, respectively, 150 days after storage. In the same study, it was also noted that the incorporation of propolis with modified atmosphere packaging provides better preservation of the fruit weight [30]. Propolis alone (EEP at $0.5 \%$ dipping dose) was also found to keep the weight loss of cucumber fruits at $15.40 \%$ in 24 days of storage, where the weight loss was $26.72 \%$ at the untreated control fruits; the combination of propolis with MAP was suggested to provide better control of the weight loss which was reported as 3.58\% [56]. The application of $2 \%$ and 3\% alcoholic extract of propolis was then recommended to provide higher efficiency in prevention of the weight loss at "Washington Navel" oranges. The efficacy of 3\% propolis in the mentioned study was significantly similar to the commercial wax which has high attention in the citrus industry [61]. Studies with papaya cv. "Golden" (Carica papaya L.) showed that the $2.5 \%$ propolis coating improves the storability of fruits by reducing the weight loss and improving some other quality characteristics [70]. However, it is also important to note that ethanol, which is the main solvent used for propolis, alone was shown to provide a blocking at stomata and results with reduction in transpiration and respiration and in conclusion in weight loss [52]. In addition to this knowledge, there is one another study suggesting that ethanol application alone does not provide any positive influence on the retention of the fruit quality due to its volatile nature [79]. In a similar study, both the aqueous and alcoholic extracts of propolis were noted to have no significant influence on the postharvest quality of "Eva" organic apple and do not prolong its storability at $5 \pm 1^{\circ} \mathrm{C}[77]$.

4.2. Effects on Chilling Injury. Storage temperature is the most important environmental factor which significantly reduces respiration, transpiration, and pathogens development, which are the main causes of weight and quality losses, but lowering the temperature below critical levels (changing depending upon the crops) causes damages on the food products, namely, chilling injury. The critical range for the temperature changes among the varieties, but it is mainly 
TABLE 2: Summary of the existing literature on the postharvest efficacy of propolis on food storability.

\begin{tabular}{|c|c|c|c|c|c|c|c|c|c|c|c|c|}
\hline Crops & Treatment (doses) & WL & $\mathrm{CI}$ & SSC & TA & $\mathrm{VC}$ & TPC & AA & $\mathrm{F}$ & S & DI & Reference \\
\hline Pomegranate & Dipping in $1.0 \%$ EEP (70\% ethanol) & + & + & + & + & + & $\mathrm{n} / \mathrm{a}$ & $\mathrm{nu}$ & $\mathrm{n} / \mathrm{a}$ & + & + & [30] \\
\hline Mango & Dipping in $2.5 \%, 3.5 \%$, and $4.5 \%$ EEP (70\% ethanol) & + & $\mathrm{n} / \mathrm{a}$ & + & + & $\mathrm{n} / \mathrm{a}$ & + & $\mathrm{n} / \mathrm{a}$ & + & $\mathrm{n} / \mathrm{a}$ & + & {$[53]$} \\
\hline Papaya & Coating with $2.5 \%$ aqueous extract & + & $\mathrm{n} / \mathrm{a}$ & nu & $\mathrm{nu}$ & $\mathrm{n} / \mathrm{a}$ & $\mathrm{n} / \mathrm{a}$ & $\mathrm{n} / \mathrm{a}$ & + & + & $\mathrm{n} / \mathrm{a}$ & {$[70]$} \\
\hline Papaya & Dipping in $1.5 \%$ and $2.0 \%$ EEP ( $70 \%$ ethanol) & + & $\mathrm{n} / \mathrm{a}$ & + & + & $\mathrm{n} / \mathrm{a}$ & $\mathrm{n} / \mathrm{a}$ & $\mathrm{n} / \mathrm{a}$ & + & $\mathrm{n} / \mathrm{a}$ & + & {$[52]$} \\
\hline Papaya & Dipping in $2.5 \%$ and $5.0 \%$ EEP ( $70 \%$ ethanol) & + & $\mathrm{n} / \mathrm{a}$ & + & $\mathrm{n} / \mathrm{a}$ & $\mathrm{n} / \mathrm{a}$ & $\mathrm{n} / \mathrm{a}$ & $\mathrm{n} / \mathrm{a}$ & + & + & $\mathrm{n} / \mathrm{a}$ & {$[71]$} \\
\hline Banana & Coating with $2.5 \%$ EEP (70\% ethanol) & + & $\mathrm{n} / \mathrm{a}$ & + & + & $\mathrm{n} / \mathrm{a}$ & $\mathrm{n} / \mathrm{a}$ & $\mathrm{n} / \mathrm{a}$ & + & + & $\mathrm{n} / \mathrm{a}$ & {$[72]$} \\
\hline on fruit & Dipping in $0.75 \%$ a & + & $\mathrm{n} / \mathrm{a}$ & + & + & $\mathrm{n} / \mathrm{a}$ & + & + & + & $\mathrm{n} / \mathrm{a}$ & $\mathrm{n} / \mathrm{a}$ & {$[73]$} \\
\hline Or: & Coating with $2.5 \%$ a & + & $\mathrm{n} / \mathrm{a}$ & + & + & $\mathrm{n} / \mathrm{a}$ & $\mathrm{n} / \mathrm{a}$ & $\mathrm{n} / \mathrm{a}$ & + & $\mathrm{n} / \mathrm{a}$ & $\mathrm{n} / \mathrm{a}$ & {$[74]$} \\
\hline ge & Dipping in $2.0 \%$ EEP (70\% ethanol) & + & $\mathrm{n} / \mathrm{a}$ & + & + & + & $\mathrm{n} / \mathrm{a}$ & $\mathrm{n} / \mathrm{a}$ & $\mathrm{n} / \mathrm{a}$ & $\mathrm{n} / \mathrm{a}$ & + & {$[54]$} \\
\hline Or: & Coating with $2.0 \%$ and $3.0 \%$ a & + & $\mathrm{n} / \mathrm{a}$ & $\mathrm{nu}$ & + & + & $\mathrm{n} / \mathrm{a}$ & $\mathrm{n} / \mathrm{a}$ & $\mathrm{n} / \mathrm{a}$ & + & + & {$[61]$} \\
\hline nber & Dipping in $0.5 \% \mathrm{EE}$ & + & + & + & $\mathrm{n} / \mathrm{a}$ & $\mathrm{n} / \mathrm{a}$ & $\mathrm{n} / \mathrm{a}$ & $\mathrm{n} / \mathrm{a}$ & nu & + & + & {$[56]$} \\
\hline ine & Dipping in $5 \%, 10 \%$, and $15 \%$ EEP ( $70 \%$ ethanol) & $\mathrm{nu}$ & $\mathrm{n} / \mathrm{a}$ & + & + & + & $\mathrm{n} / \mathrm{a}$ & $\mathrm{n} / \mathrm{a}$ & $\mathrm{n} / \mathrm{a}$ & + & $\mathrm{n} / \mathrm{a}$ & {$[75]$} \\
\hline cherr & Dipping in $0.5 \%, 1.0 \%, 1.5 \%$, and $2.0 \%$ & + & $\mathrm{n} / \mathrm{a}$ & + & + & + & $\mathrm{n} / \mathrm{a}$ & $\mathrm{n} / \mathrm{a}$ & + & $\mathrm{n} / \mathrm{a}$ & $\mathrm{n} / \mathrm{a}$ & {$[76]$} \\
\hline $\mathrm{Ra}$ & Edible film coating wit & $\mathrm{n} / \mathrm{a}$ & $\mathrm{n} / \mathrm{a}$ & $\mathrm{n} / \mathrm{a}$ & $\mathrm{n} / \mathrm{a}$ & $\mathrm{n} / \mathrm{a}$ & $\mathrm{n} / \mathrm{a}$ & $\mathrm{n} / \mathrm{a}$ & $\mathrm{n} / \mathrm{a}$ & + & + & {$[63]$} \\
\hline vberry & Edible film with $10^{\circ}$ & $\mathrm{n} / \mathrm{a}$ & $\mathrm{n} / \mathrm{a}$ & $\mathrm{n} / \mathrm{a}$ & $\mathrm{n} / \mathrm{a}$ & $\mathrm{n} / \mathrm{a}$ & $\mathrm{n} / \mathrm{a}$ & $\mathrm{n} / \mathrm{a}$ & $\mathrm{n} / \mathrm{a}$ & $\mathrm{n} / \mathrm{a}$ & + & [64] \\
\hline Pear & $\begin{array}{c}\text { Spraying with } 30.0 \mathrm{mg} / \mathrm{mL} \text { or } 6.0 \mathrm{mg} / \mathrm{mL} \text { EEP }(70 \% \\
\text { ethanol) }\end{array}$ & $\mathrm{n} / \mathrm{a}$ & $\mathrm{n} / \mathrm{a}$ & $\mathrm{n} / \mathrm{a}$ & $\mathrm{n} / \mathrm{a}$ & $\mathrm{n} / \mathrm{a}$ & $\mathrm{n} / \mathrm{a}$ & $\mathrm{n} / \mathrm{a}$ & $\mathrm{n} / \mathrm{a}$ & $\mathrm{n} / \mathrm{a}$ & + & {$[66]$} \\
\hline App & $\begin{array}{c}\text { Dipping in } 1.5 \% \text { and } 2.5 \% \text { EEP ( } 70 \% \text { ethyl alcohol and } \\
\text { aqueous extract) }\end{array}$ & 11 & $\mathrm{n} / \mathrm{a}$ & nu & nu & $\mathrm{n} / \mathrm{a}$ & $\mathrm{n} / \mathrm{a}$ & $\mathrm{n} / \mathrm{a}$ & $\mathrm{n} / \mathrm{a}$ & u & $\mathrm{n} / \mathrm{a}$ & {$[77]$} \\
\hline $\begin{array}{l}\text { Pomegranate } \\
\text { juice }\end{array}$ & 1 drop of EEP ( $1: 10$ in $70 \%$ ethanol) per $250 \mathrm{ml}$ of juice & $\mathrm{n} / \mathrm{a}$ & $\mathrm{n} / \mathrm{a}$ & + & + & + & $\mathrm{n} / \mathrm{a}$ & + & $\mathrm{n} / \mathrm{a}$ & $\mathrm{n} / \mathrm{a}$ & + & {$[62]$} \\
\hline
\end{tabular}

WL: weight loss; CI: chilling injury; SSC: soluble solids concentration; TA: titratable acidity; VC: vitamin C (ascorbic acid); TPC: total phenolic content; AA: antioxidant activity; F: firmness (textural quality); S: sensory or visual acceptability; DI: decay incidence; n/a: no data available; +: positive influence; -: negative influence; nu: neuter effect.

below $5^{\circ} \mathrm{C}-13^{\circ} \mathrm{C}[3]$. Low temperatures cause various physiological and biochemical changes which lead to the development of different symptoms, for example, surface pitting, flavor loss, discoloration, wilting, and internal breakdown. Dipping of pomegranate and cucumber fruits into $1.0 \%$ and $0.5 \%$, respectively, of ethanolic extracts of propolis, was noted to reduce the severity of chilling injury on the fruits $[30,56]$. No recommendations were given on the mechanism behind this preservation, but the results may suggest that the increase in the phenolic contents and ascorbic acid in pomegranate fruits might be the main cause of this preservation.

4.3. Effects on Soluble Solids Content and Titratable Acidity. Soluble solids concentration (SSC) and titratable acidity (TA) are the main determinants of the food taste. Thus, the prevention of the losses of SSC and TA is highly important for keeping the acceptability of the foods by the consumers. The effect of propolis on the fruits' SSC and TA was noted to vary among the fruit species such that no significant influence was reported for the SSC and TA of mango fruits [53], papaya fruits [70], and orange fruits [61], while a positive influence on the prevention of both SSC and TA was noted for pomegranate fruits [30], mango fruits [55], papaya fruits [52], banana fruits [72], dragon fruits [73], orange fruits $[54,74]$, and pomegranate juice [62]. The positive influence of propolis extracts on the SSC levels could be explained by the similar mechanism of weight loss prevention, which is the formation of a semipermeable and biodegradable barrier around the food which suppresses some biochemical reactions, including the most important one: respiration $[3,73,80]$. A similar mechanism exists for the TA, and in general it is known that the increase in respiration rate causes a decrease in $\mathrm{TA}$; thus, reduction of the respiration provides a reservation of the TA in fruits [81].

4.4. Effects on Vitamin C (Ascorbic Acid) Contents. Vitamin C (VC, ascorbic acid) is an important water soluble compound and has high antioxidant capacity, helping human cells in fighting with microbial infections, protecting cells from damage, and reducing oxidative stress in human body. Although there are numerous studies about the influence of propolis on the storability of food products, most of these studies had not reported any positive or negative influence on the VC content. In a limited number of studies, it was noted that the postharvest application of propolis has a positive influence on the prevention of $\mathrm{VC}$ contents of pomegranate fruits [30], orange fruits $[54,61]$, tangerine fruits [75], and pomegranate juice [62]. Vitamin $C$ is known to have a decreasing trend during the storage period of the fruits, and propolis was found to have a positive influence on the prevention of the decrease in VC at "Washington Navel" orange fruits. Further studies are highly necessary about the efficacy of propolis on the VC contents of foods during storage.

4.5. Effects on Phenolic Contents. Phenolic compounds (PCs) are important phytochemicals found in most plant tissues, which are synthesized through secondary metabolisms and are called secondary plant metabolites. Even though they are not nutrients, they possess numerous bioactive properties and are known to have high antioxidant activity and provide health-protective effects. They also have significant roles in the plants' defensive system against pests, diseases, or 
abnormal environmental conditions [82]. Therefore, prevention and/or inducement of the biosynthesis of the phenolic compounds in food products might be a cause of the preservation of the postharvest quality of foods. Higher rate of respiration is known to result in the degradation of certain phenolic compounds. Thus, the prevention of respiration might be a reason for the prevention of the degradation and reduction of phenolic compounds. The number of studies about changes in phenolic compounds due to the application of propolis is limited but the results are valuable. It was noted that propolis treatment prevents the degradation of the phenolic compounds at mango $[53,55]$ and dragon fruits [73].

4.6. Effects on Antioxidant Activity. Antioxidant activity is an important example of functional benefits of plants which directly scavenge free radicals and prevent/reduce the oxidation of lipids, proteins, DNA, or other molecules and/or indirectly prevent the formation of free radicals [83]. Thus, the change in the antioxidant activity of the foods during storage is an important parameter and always needs to be at higher levels. Herein, the effects of propolis on the antioxidant activity of different food products were summarized. For example, no significant influence was noted for the antioxidant activity of pomegranate fruits [30] and mango fruits [53]. Positive influence for the propolis treatment on the prevention of the antioxidant activity was also suggested for dragon fruit [73] and pomegranate juice [62].

4.7. Effects on Textural Quality. Textural quality of foods, which is mainly described by firmness, is also important for the consumers' acceptability of the food products. Propolis treatment, as suggested previously, provide a semipermeable and biodegradable film on fruit surface and regulates the movement of gases and water in/out from the food tissues; thus, it maintains cell turgidity and firmness of fruit $[52,72,73]$. In confirmation of this knowledge, numerous studies reported success about the preventive characteristics of propolis for the fruit firmness, such as in mango fruits [55], papaya fruits $[52,70,71]$, banana fruits [72], dragon fruits [73], orange fruits [74], and sweet cherry [76].

4.8. Effects on Visual or Sensory Acceptability. Visual or sensory acceptability might be accepted as the aggregate of all parameters. In some of the studies, visual and sensory acceptability of the foods was discussed separately, and it was noted that propolis have a high influence on the acceptability of pomegranate fruit [30], mango fruit [53], papaya fruit $[70,71]$, banana fruit [72], orange fruit [61], and cucumber fruit [56]. The application of propolis extracts to fruits and vegetables, either by dipping or coating, enhances the sensory quality and microbial durability of the foods. It also contributes to the biochemical and physical characteristics of fruits and vegetables, thereby maintaining the postharvest quality of products during storage. The main disadvantage of the propolis extracts might be as a result of its unique flavor and volatiles, which was noted to cause some alterations on the sensory characteristics of some foods [84].

\section{Conclusions}

In conclusion, it is clear from the previously discussed information that although the chemical composition of the propolis significantly vary according to the plant source and season, it has a very rich chemical composition, specifically its phenolic compounds, and has a high antioxidant activity. Studies on its antimicrobial and fungicidal effects showed that it is very effective in controlling pathogenic decay. However, the actual mechanism is still not well-understood and further studies are required. Up until now, existing information suggests that the antimicrobial efficacy might be due to its direct influence on the biochemical structures of pathogens or its indirect influence on the biochemical reactions of food products which induce resistant against pathogens. Additionally, published scientific literature suggests that the positive influence of the propolis on the postharvest storability of food products is due to its hydrophobic composites and high phenolic concentration which provides a capability to form biodegradable barrier on fruit surface. This barrier prevents the movement of water and gases through the food surface, which in turn reduce the transpiration and respiration and improve the storability of food products. However, there is still a need to deeply investigate the effects of propolis on the biochemical composition, enzymatic activities, and possible biochemical reactions in food products. This would improve our understanding about the possible mechanism and may lead us to develop industrial biopreservatives from propolis for postharvest applications.

\section{Data Availability}

All data used to support the findings of this study are included within the paper.

\section{Conflicts of Interest}

The authors declare no conflicts of interest.

\section{Acknowledgments}

This research was funded by the Natural Science Foundation in Jiangxi Province (20181BCB24005).

\section{References}

[1] R. Lal, "Climate change, soil carbon dynamics, and global food security," in Climate Change and Global Food Security, R. Lal, N. Uphoff, B. A. Stewart, and D. O. Hansen, Eds., CRC Press, Boca Raton, FL, USA, pp. 113-143, 2005.

[2] Y. Kang, S. Khan, and X. Ma, "Climate change impacts on crop yield, crop water productivity and food security-a review," Progress in Natural Science, vol. 19, pp. 1665-1674, 2019.

[3] İ. Kahramanoğlu, "Introductory chapter: postharvest physiology and technology of horticultural crops," in Postharvest 
Handling, P. Handling and İ. Kahramanoğlu, Eds., InTech Open, London, UK, pp. 1-5, 2017.

[4] M. B. Cole, M. A. Augustin, M. J. Robertson, and J. M. Manners, "The science of food security," Npj Science of Food, vol. 2, no. 1, p. 14, 2018.

[5] FAO (Food and Agriculture Organisation), Hunger and Food Insecurity, FAO (Food and Agriculture Organisation), Rome. Italy, 2020, http://www.fao.org/hunger/en/.

[6] P. Gennari, A. Heyman, and M. Kainu, FAO Statistical Pocketbook: World Food and Agriculture-Food and Agriculture Organisation, United Nations, Rome, Italy, 2015.

[7] U. M. Carthy, I. Uysal, R. Badia-Melis, S. Mercier, C. O'Donnel, and A. Ktenioudaki, "Global food security-issues, challenges and technological solutions," Trends in Food Science \& Technology, vol. 77, pp. 11-20, 2018.

[8] D. Gunders and J. W. Bloom, How America Is Losing up to 40 Percent of its Food from Farm to Fork to Landfill, Natural Resources Defense Council, New York City, NY, USA, 2017.

[9] Z. Berk, "Postharvest changes," in Citrus Fruit Processing, Z. Berk, Ed., pp. 95-105, Academic Press, Cambridge, MA, USA, 2016.

[10] W. Hao, H. Li, M. Hu, L. Yang, and M. Rizwan-ul-Haq, "Integrated control of citrus green and blue mold and sour rot by Bacillus amyloliquefaciens in combination with tea saponin," Postharvest Biology and Technology, vol. 59, no. 3, pp. 316-323, 2011.

[11] S. Koch, A. Epp, M. Lohmann, and G.-F. Böl, "Pesticide residues in food: attitudes, beliefs, and misconceptions among conventional and organic consumers," Journal of Food Protection, vol. 80, no. 12, pp. 2083-2089, 2017.

[12] R. R. Sharma, D. Singh, and R. Singh, "Biological control of postharvest diseases of fruits and vegetables by microbial antagonists: a review," Biological Control, vol. 50, no. 3, pp. 205-221, 2009.

[13] L. Palou, J. Smilanick, and S. Droby, "Alternatives to conventional fungicides for the control of citrus postharvest green and blue molds," Stewart Postharvest Review, vol. 4, no. 2, pp. 1-16, 2008.

[14] İ. Kahramanoğlu, C. Chen, Y. Chen, J. Chen, Z. Gan, and C. Wan, "Improving storability of "nanfeng" mandarins by treating with postharvest hot water dipping," Journal of Food Quality, vol. 2020, Article ID 8524952, 12 pages, 2020.

[15] C. Wan, İ. Kahramanoğlu, J. Chen, Z. Gan, and C. Chen, "Effects of hot air treatments on postharvest storage of Newhall navel orange," Plants, vol. 9, no. 2, p. 170, 2020.

[16] J. L. Smilanick, M. F. Mansour, F. M. Gabler, and D. Sorenson, "Control of citrus postharvest green mold and sour rot by potassium sorbate combined with heat and fungicides," Postharvest Biology and Technology, vol. 47, no. 2, pp. 226238, 2008.

[17] K. Papoutsis, M. M. Mathioudakis, J. H. Hasperué, and V. Ziogas, "Non-chemical treatments for preventing the postharvest fungal rotting of citrus caused by Penicillium digitatum (green mold) and Penicillium italicum (blue mold)," Trends in Food Science \& Technology, vol. 86, pp. 479-491, 2019.

[18] O. J. Caleb, P. V. Mahajan, F. A.-J. Al-Said, and U. L. Opara, "Modified atmosphere packaging technology of fresh and fresh-cut produce and the microbial consequences-a review," Food and Bioprocess Technology, vol. 6, no. 2, pp. 303-329, 2013.

[19] K. T. H. Dang, Z. Singh, and E. E. Swinny, "Edible coatings influence fruit ripening, quality, and aroma biosynthesis in mango fruit," Journal of Agricultural and Food Chemistry, vol. 56, no. 4, pp. 1361-1370, 2008.
[20] S. Saucedo-Pompa, R. Rojas-Molina, A. F. Aguilera-Carbó et al., "Edible film based on candelilla wax to improve the shelf life and quality of avocado," Food Research International, vol. 42, no. 4, pp. 511-515, 2009.

[21] Z. Xin, Q. OuYang, C. Wan et al., "Isolation of antofine from Cynanchum atratum bunge (Asclepiadaceae) and its antifungal activity against Penicillium digitatum," Postharvest Biology and Technology, vol. 157, Article ID 110961, 2019.

[22] M. A. Gatto, L. Sergio, A. Ippolito, and D. Di Venere, "Phenolic extracts from wild edible plants to control postharvest diseases of sweet cherry fruit," Postharvest Biology and Technology, vol. 120, pp. 80-187, 2016.

[23] J. Chen, Y. Shen, C. Chen, and C. Wan, "Inhibition of key citrus postharvest fungal strains by plant extracts in vitro and in vivo: a review," Plants, vol. 8, no. 2, p. 26, 2019.

[24] İ. Kahramanoğlu, "Effects of lemongrass oil application and modified atmosphere packaging on the postharvest life and quality of strawberry fruits," Scientia Horticulturae, vol. 256, Article ID 108527, 2019.

[25] B. Prakash, A. Kedia, P. K. Mishra, and N. K. Dubey, "Plant essential oils as food preservatives to control moulds, mycotoxin contamination and oxidative deterioration of agrifood commodities-potentials and challenges," Food Control, vol. 47, pp. 381-391, 2015.

[26] H. Boubaker, H. Karim, A. El Hamdaoui et al., "Chemical characterization and antifungal activities of four thymus species essential oils against postharvest fungal pathogens of citrus," Industrial Crops and Products, vol. 86, pp. 95-101, 2016.

[27] P. Gutiérrez-Martínez, A. Ramos-Guerrero, C. RodríguezPereida, L. Coronado-Partida, J. Angulo-Parra, and R. González-Estrada, "Chitosan for postharvest disinfection of fruits and vegetables," in Postharvest Disinfection of Fruits and Vegetables, M. W. Siddiqui, Ed., Academic Press, Cambridge, MA, USA, pp. 231-241, 2018.

[28] G. Adiletta, M. Pasquariello, L. Zampella, F. Mastrobuoni, M. Scortichini, and M. Petriccione, "Chitosan coating: a postharvest treatment to delay oxidative stress in loquat fruits during cold storage," Agronomy, vol. 8, no. 4, p. 54, 2018.

[29] A. E. Özdemir, E. E. Çandır, M. Kaplankıran, E. M. Soylu, N. Şahinler, and A. Gül, "The effects of ethanol-dissolved propolis on the storage of grapefruit cv: star ruby," Turkish Journal of Agriculture and Forestry, vol. 34, pp. 155-162, 2010.

[30] İ. Kahramanoğlu, M. Aktaş, and Ş. Gündüz, "Effects of fludioxonil, propolis and black seed oil application on the postharvest quality of "wonderful" pomegranate," PLoS One, vol. 13, no. 5, Article ID e0198411, 2018.

[31] V. Bankova, A. Dyulgerov, S. Popov et al., "Propolis produced in Bulgaria and Mongolia: phenolic compounds and plant origin," Apidologie, vol. 23, no. 1, pp. 79-85, 1992.

[32] S. Ciftci-Yilmaz, Z. N. Azman, K. Kosem, E. Gunduz, and R. G. Grenman, "Evaluating antioxidant capacity of different propolis samples from konya, Turkey and their inhibitory effect on head and neck cancer cells," BioRxiv, 2017.

[33] Y.-Z. Zheng, G. Deng, Q. Liang, D.-F. Chen, R. Guo, and R.-C. Lai, "Antioxidant activity of quercetin and its glucosides from propolis: a theoretical study," Scientific Reports, vol. 7, no. 1, 2017.

[34] G. Horváth, Á. Farkas, N. Papp et al., "Natural substances from higher plants as potential anti-MRSA agents," Studies in Natural Products Chemistry, Elsevier, Amsterdam, Netherlands, pp. 63-110, 2016.

[35] E. L. Ghisalberti, "Propolis: a review," Bee World, vol. 60, no. 2, pp. 59-84, 1979. 
[36] V. C. Toreti, H. H. Sato, G. M. Pastore, and Y. K. Park, "Recent progress of propolis for its biological and chemical compositions and its botanical origin," Evidence-Based Complementary and Alternative Medicine, vol. 2013, Article ID 697390, 13 pages, 2013.

[37] G. C.-F. Chan, K.-W. Cheung, and D. M.-Y. Sze, "The immunomodulatory and anticancer properties of propolis," Clinical Reviews in Allergy \& Immunology, vol. 44, no. 3, pp. 262-273, 2013.

[38] B. Machado, T. Pulcino, A. Silva, D. Melo, R. Silva, and I. Mendonça, "Propolis as an alternative in prevention and control of dental cavity," Journal of Apitherapy, vol. 1, no. 2, pp. 47-50, 2016.

[39] R. S. Veiga, S. De Mendonça, P. B. Mendes et al., “Artepillin C and phenolic compounds responsible for antimicrobial and antioxidant activity of green propolis and Baccharis dracunculifolia DC," Journal of Applied Microbiology, vol. 122, no. 4, pp. 911-920, 2017.

[40] S. I. Anjum, A. Ullah, K. A. Khan et al., "Composition and functional properties of propolis (bee glue): a review," Saudi Journal of Biological Sciences, vol. 26, no. 7, pp. 1695-1703, 2019.

[41] A. A. Al-Ghamdi, N. I. M. Bayaqoob, A. I. Rushdi et al., "Chemical compositions and characteristics of organic compounds in propolis from Yemen," Saudi Journal of Biological Sciences, vol. 24, no. 5, pp. 1094-1103, 2017.

[42] S. Chaa, M. Y. Boufadi, S. Keddari et al., "Chemical composition of propolis extract and its effects on epirubicin-induced hepatotoxicity in rats," Revista Brasileira de Farmacognosia, vol. 29, no. 3, pp. 294-300, 2019.

[43] M. Wozniak, M. Mrówczynska, A. Waskiewicz, T. Rogozinski, and I. Ratajczak, "The role of seasonality on the chemical composition, antioxidant activity and cytotoxicity of Polish propolis in human erythrocytes," Revista Brasileira de Farmacognosia, vol. 29, no. 3, pp. 301-308, 2019.

[44] P. Ristivojeviæ, I. Dimkiæ, E. Guzelmeric et al., "Profiling of Turkish propolis subtypes: comparative evaluation of their phytochemical compositions, antioxidant and antimicrobial activities," $L W T$, vol. 95, pp. 367-379, 2018.

[45] D. Valencia, E. Alday, R. Robles-Zepeda et al., "Seasonal effect on chemical composition and biological activities of Sonoran propolis," Food Chemistry, vol. 131, no. 2, pp. 645-651, 2012.

[46] P. Ristivojević, F. L. Andrić, J. D. Trifković et al., "Pattern recognition methods and multivariate image analysis in HPTLC fingerprinting of propolis extracts," Journal of Chemometrics, vol. 28, pp. 301-310, 2014.

[47] D. Milojković Opsenica, P. Ristivojević, J. Trifković, I. Vovk, D. Lušić, and Z. Tešić, "TLC fingerprinting and pattern recognition methods in the assessment of authenticity of poplar-type propolis," Journal of Chromatographic Science, vol. 54, no. 7, pp. 1077-1083, 2016.

[48] J. Bertrams, N. Kunz, and M. Müller, "Phenolic compounds as marker compounds for botanical origin determination of German propolis samples based on TLC and TLC-MS," Journal of Applied Botany and Food Quality, vol. 153, pp. 143-153, 2013.

[49] M. El-Otmani, A. Ait-Oubahou, and L. Zacarías, "Citrus spp.: orange, mandarin, tangerine, clementine, grapefruit, pomelo, lemon and lime," in Postharvest Biology and Technology of Tropical and Subtropical Fruits, E. M. Yahia, Ed., pp. 437-516, Woodhead Publishing, Sawston, UK, 2011.

[50] O. K. Mirzoeva, R. N. Grishanin, and P. C. Calder, "Antimicrobial action of propolis and some of its components: the effects on growth, membrane potential and motility of bacteria," Microbiological Research, vol. 152, no. 3, pp. 239-246, 1997.

[51] A. Borges, C. Ferreira, M. J. Saavedra, and M. Simões, "Antibacterial activity and mode of action of ferulic and gallic acids against pathogenic bacteria," Microbial Drug Resistance, vol. 19, no. 4, pp. 256-265, 2013.

[52] A. Ali, C. K. Cheong, and N. Zahid, "Composite effect of propolis and gum Arabic to control postharvest anthracnose and maintain quality of papaya during storage," International Journal of Agriculture and Biology, vol. 16, pp. 1117-1122, 2014.

[53] B.-H. Mattiuz, M.-N. Ducamp-Collin, C. F. M. Mattiuz et al., "Effect of propolis on postharvest control of anthracnose and quality parameters of "kent" mango," Scientia Horticulturae, vol. 184, pp. 160-168, 2015.

[54] I. F. M. Badawy, "Effect of ethanol-extracted propolis on fruit quality and storability of balady oranges during cold storage," Assiut Journal of Agricultural Sciences, vol. 47, no. 4, pp. 156-166, 2016.

[55] A. D. Al-Qurashi and M. A. Awad, "Postharvest ethanolic extract of propolis treatment affects quality and biochemical changes of "hindi-besennara" mangos during shelf life," Scientia Horticulturae, vol. 233, pp. 520-525, 2018.

[56] İ. Kahramanoğlu and S. Usanmaz, "Improving postharvest storage quality of cucumber fruit by modified atmosphere packaging and biomaterials," HortScience, vol. 54, no. 11, pp. 2005-2014, 2019.

[57] M. F. S. Alsayed, A. Hashem, A. A. Al-Hazzani, and E. F. Abd Allah, "Biological control of yeast contamination of industrial foods by propolis," Saudi Journal of Biological Sciences, vol. 27, no. 3, pp. 935-946, 2020.

[58] N. Takaisi-Kikuni and H. Schilcher, "Electron microscopic and microcalorimetric investigations of the possible mechanism of the antibacterial action of a defined propolis provenance," Planta Medica, vol. 60, no. 3, pp. 222-227, 1994.

[59] E. M. Soylu, A. E. Ozdemir, E. Erturk, N. Sahinler, and S. Soylu, "Antifungal activity ofpropolis against postharvest disease agent Penicillium digitatum," Asian Journal of Chemistry, vol. 20, pp. 4823-4830, 2008.

[60] S. Z. Yang, L. T. Peng, X. J. Su et al., "Bioassay-guided isolation and identification of antifungal components from propolis against Penicillium italicum," Food Chemistry, vol. 127, no. 1, pp. 210-215, 2011.

[61] H. E. M. El-Badawy, M. H. M. Baiea, and E. A. A. A. ElMoneim, "Efficacy of propolis and wax coatings in improving fruit quality of "washington" navel orange under cold storage," Research Journal of Agriculture and Biological Sciences, vol. 8, no. 5, pp. 420-428, 2012.

[62] I. Kahramanoglu and S. Usanmaz, "Effects of propolis and black seed oil on the shelf life of freshly squeezed pomegranate juice," Food Science and Nutrition Studies, vol. 1, no. 2, pp. 114-121, 2017.

[63] M. A. Moreno, A. M. Vallejo, A.-R. Ballester et al., "Antifungal edible coatings containing Argentinian propolis extract and their application in raspberries," Food Hydrocolloids, vol. 107, Article ID 105973, 2020.

[64] Z. N. Correa-Pacheco, S. Bautista-Baños, M. D. L. RamosGarcía, M. D. C. Martínez-González, and J. Hernández-Romano, "Physicochemical characterization and antimicrobial activity of edible propolis-chitosan nanoparticle films," Progress in Organic Coatings, vol. 137, Article ID 105326, 2019.

[65] M. D. C. Martínez-González, S. Bautista-Baños, Z. N. CorreaPacheco et al., "Effect of nanostructured chitosan/propolis coatings on the quality and antioxidant capacity of strawberries during storage," Coatings, vol. 10, no. 2, p. 90, 2020. 
[66] M. Loebler, C. Sánchez, E. Muchagato Maurício et al., "Potential application of propolis extracts to control the growth of Stemphylium vesicarium in "rocha" pear," Applied Sciences, vol. 10, no. 6, p. 1990, 2020.

[67] R. Trujillo and N. Laible, "Reversible inhibition of spore germination by alcohols 1," Applied Microbiology, vol. 20, no. 4 , pp. $620-623,1970$.

[68] I. M. S. Utama, R. B. H. Wills, S. Ben-yehoshua, and C. Kuek, "In vitro efficacy of plant volatiles for inhibiting the growth of fruit and vegetable decay microorganisms," Journal of Agricultural and Food Chemistry, vol. 50, no. 22, pp. 6371-6377, 2002.

[69] T. H. L. Bernardo, R. C. Sales Santos Veríssimo, V. Alvino et al., "Antimicrobial analysis of an antiseptic made from ethanol crude extracts of P. granatum and E. uniflora in wistar rats against Staphylococcus aureus and Staphylococcus epidermidis," The Scientific World Journal, vol. 2015, Article ID 751791, 7 pages, 2015.

[70] M. C. Da Cunha, F. R. Passos, F. Q. Mendes, and A. M. X. De Carvalho, "Propolis extract from different botanical sources in postharvest conservation of papaya," Acta Scientiarum Technol, vol. 40, no. 1, 2018.

[71] F. R. Passos, F. Q. Mendes, M. D. C. E. Pinto, E. A. Araújo, and A. M. X. D. Carvalho, "Propolis extract in postharvest conservation solo papaya cv "golden"” Semina: Ciências Agrárias, vol. 37, no. 6, pp. 4039-4050, 2016.

[72] F. R. Passos, F. Q. Mendes, M. C. D. Cunha, M. T. Pigozzi, and A. M. X. D. Carvalho, "Propolis extract in postharvest conservation banana "prata"” Revista Brasileira de Fruticultura, vol. 38, no. 2, 2016.

[73] N. Zahid, A. Ali, Y. Siddiqui, and M. Maqbool, "Efficacy of ethanolic extract of propolis in maintaining postharvest quality of dragon fruit during storage," Postharvest Biology and Technology, vol. 79, pp. 69-72, 2013.

[74] F. R. Passos, F. Q. Mendes, M. C. Da Cunha, and A. M. X. De Carvalho, "Propolis extract coated in "Pera" orange fruits: an alternative to cold storage," African Journal of Agricultural Research, vol. 11, no. 23, pp. 2043-4049, 2016.

[75] R. E. Putra, F. Reizandy, A. Faizal, and I. Kinasih, "Effication of local propolis as edible coating of tangerine cultivar garut (citrus reticulata blanco)," IOP Conference Series: Earth and Environmental Science, vol. 187, no. 1, Article ID 012025, 2018.

[76] Y. Gong, Y. Gao, J. Huang, M. Xu, and B. Xiong, "Study on the preservation effect of propolis on sweet cherry," IOP Conference Series: Earth and Environmental Science, vol. 474, Article ID 032029, 2020.

[77] F. A. D. C. Mariano-Nasser, "Modified atmosphere using propolis in post-harvested "eva" organic apple," Emirates Journal of Food and Agriculture, vol. 32, no. 3, pp. 172-180, 2020.

[78] X. Zhu, Q. Wang, J. Cao, and W. Jiang, "Effects of chitosan coating on postharvest quality of mango (mangifera indical. cv tainong) fruits," Journal of Food Processing and Preservation, vol. 32, no. 5, pp. 770-784, 2008.

[79] F. M. Gabler, J. L. Smilanick, J. M. Ghosoph, and D. A. Margosan, "Impact of postharvest hot water or ethanol treatment of table grapes on gray mold incidence, quality, and ethanol content," Plant Disease, vol. 89, no. 3, pp. 309-316, 2005.

[80] F. Kittur, N. Saroja, R. N. Habibunnisa, and R. Tharanathan, "Polysaccharide-based composite coating formulations for shelf-life extension of fresh banana and mango," European Food Research and Technology, vol. 213, no. 4-5, pp. 306-311, 2001.
[81] A. M. El-Anany, G. F. A. Hassan, and F. M. A. Rehab, "Effects of edible coatings on the shelf-life and quality of anna apple (Malus domestica borkh) during cold storage," Journal of Food Science and Technology, vol. 7, pp. 5-11, 2009.

[82] J. B. Harborne, "Plant phenolics," in Secondary Plant Products, E. A. Bell, B. V. Charlwood, and B. Archer, Eds., pp. 330-402, Springer, Berlin, Germany, 1980.

[83] D. Huang, B. Ou, and R. L. Prior, "The chemistry behind antioxidant capacity assays," Journal of Agricultural and Food Chemistry, vol. 53, no. 6, pp. 1841-1856, 2005.

[84] K. Pobiega, K. Kraśniewska, and M. Gniewosz, “Application of propolis in antimicrobial and antioxidative protection of food quality-a review," Trends in Food Science \& Technology, vol. 83, pp. 53-62, 2019. 